\title{
Influence of Heat Treatment on Biocorrosion and Hemocompatibility of Biodegradable Mg-35Zn-3Ca Alloy
}

\author{
Jeong-Hui Ji, ${ }^{1}$ Il-Song Park, ${ }^{2}$ Yu-Kyoung Kim, ${ }^{1}$ Sook-Jeong Lee, ${ }^{3}$ \\ Tae-Sung Bae, ${ }^{1}$ and Min-Ho Lee ${ }^{1}$ \\ ${ }^{1}$ Department of Dental Biomaterials and Institute of Biodegradable Material, Institute of Oral Bioscience and BK21 Plus Project, \\ School of Dentistry, Chonbuk National University, Jeonju 561-756, Republic of Korea \\ ${ }^{2}$ Division of Advanced Materials Engineering and Institute of Biodegradable Material, Chonbuk National University, \\ Jeonju 561-756, Republic of Korea \\ ${ }^{3}$ Department of New Drug Discovery and Development, Chungnam National University, Yuseong, Daejeon 305-764, Republic of Korea
}

Correspondence should be addressed to Min-Ho Lee; lmh@jbnu.ac.kr

Received 19 December 2014; Accepted 21 January 2015

Academic Editor: Jinghuai Zhang

Copyright (C) 2015 Jeong-Hui Ji et al. This is an open access article distributed under the Creative Commons Attribution License, which permits unrestricted use, distribution, and reproduction in any medium, provided the original work is properly cited.

Mg-35Zn-3Ca (wt.\%) alloy containing nontoxic and biocompatible $\mathrm{Zn}$ and $\mathrm{Ca}$ as alloying elements was prepared and subjected to heat treatment and artificial aging for different duration of time to reduce its rate of degradation. Solution heat treatment was performed at $310^{\circ} \mathrm{C}$ while artificial aging was performed at $170^{\circ} \mathrm{C}$ for $0,2.5,5.0,7.5$, and $10.0 \mathrm{~h}$ and they were designated as AT0, AT1, AT2, AT3, and AT4, respectively. The finest and most homogenous reticulum was observed on the surface of the AT2 group. The result of immersion test in Hank's balanced salt solution (HBSS) showed that the corrosion rate of the AT2 group was $2.32 \mathrm{mg} /\left(\mathrm{cm}^{2}\right.$ day), which was significantly lower as compared to other groups $(P<0.05)$. The hemolysis value was $\leq 5 \%$ in all groups, indicating no toxicity during short-term blood reaction.

\section{Introduction}

Implants are widely used for the replacement and treatment of abnormally functioning bone tissues due to diseases or injuries. Among the various types of implants that are currently being used, ceramic- or polymer-based implants have unsatisfactory mechanical properties while metal-based ones are considered suitable for load bearing implant applications due to their superior mechanical strength and durability. Stainless steel, titanium and its alloys, and Co-Cr alloys are some of the commonly used materials for fabricating metallic implants. However, these implants pose a high risk of release of toxic heavy metals or generating fine metallic debris particles induced by corrosion or wear or by tribocorrosion, which could cause inflammation in the surrounding tissues [1-5]. In addition, the difference in Young's modulus between these implants and bone tissues could cause stress-shielding effect, resulting in stress concentration on the contact plane between the natural bone and the implant. This leads to a reduction of the stimuli required for the new bone growth, thereby lowering the success rate of the implant [6].

$\mathrm{Mg}$ and its alloys possess a low density, high mechanical strength, and fracture toughness. In addition, they are biocompatible and biodegradable [7]. Young's modulus of $\mathrm{Mg}$ and its alloys are closer to the natural bone than stainless steels, titanium and its alloys, and $\mathrm{Co}-\mathrm{Cr}$ alloys. $\mathrm{Mg}$ is the fourth abundant ion in the human body and it is an essential component for human metabolism. The daily $\mathrm{Mg}$ intake of a normal adult is $300-400 \mathrm{mg}$ and the excess $\mathrm{Mg}$ ions are excreted via urine [8-12]. $\mathrm{Mg}$, which is a natural component of bone tissues, helps bone growth and increases bone strength [13]. These attributes form the basis that $\mathrm{Mg}$ and its alloys can be explored towards the development of degradable biomaterials. For load-bearing application, biodegradable implants must be retained in the body for at least $12-18$ weeks, a time period which is usually required for natural growth of bone tissues after treatment or surgery, while maintaining sufficient mechanical strength $[14,15]$. 
Unfortunately, $\mathrm{Mg}$ and its alloys undergo rapid corrosion in chloride containing solutions such as body fluid, resulting in the generation of a huge volume of hydrogen gas with alkalinization of the medium [16]. The hydrogen gas thus generated could cavern under the subcutaneous tissue and under a worst scenario, the hydrogen gas bubbles could block the blood flow, causing death of the patient [8]. Thus, studies on purification, alloying, and surface coating have been explored to resolve the rapid biodegradation of $\mathrm{Mg}$ and its alloys.

Among the various alloys evaluated for biodegradable implant applications, Al-Zn based $\mathrm{Mg}$ alloys such as AZ91 and AZ31, as well as rare earth based $\mathrm{Mg}$ alloys such as LAE442 and WE43, have received considerable attention. However, when $\mathrm{Al}-\mathrm{Zn}$ based $\mathrm{Mg}$ alloys are used as degradable implants, the accumulation of aluminum in the body could cause neurogenic disorders such as Alzheimer's disease, particularly dementia, and senile dementia [17]. In case of rare earth based $\mathrm{Mg}$ alloys, cerium, praseodymium, and yttrium show hepatotoxicity and hence they are considered inappropriate for use as degradable implants [18]. Calcium is an important component of the natural bone. As a biomaterial, it has advantages for being essential in cellular signal transduction and for having density similar to that of the bone [19]. When $\mathrm{Ca}$ is added to $\mathrm{Mg}$ alloy, $\mathrm{Mg}_{2} \mathrm{Ca}$ with high melting point is formed and a protective oxide layer is also formed to improve corrosion resistance, thereby increasing hardness and creep resistance [20]. Zinc is one of the typical inorganic matters that constitutes somatic cells and regulates physiological functions. Its deficiency in the body could cause various anomalies such as low birth weight during delivery and growth and developmental problems. If $\mathrm{Zn}$ and $\mathrm{Ca}$ are added to $\mathrm{Mg}$, a stable intermetallic compound $\mathrm{Ca}_{2} \mathrm{Mg}_{6} \mathrm{Zn}_{3}$ is formed that could help in age-hardening [21] and in increasing the tensile strength and ductility of the alloy [22].

In the present study, to reduce the biodegradation rate of $\mathrm{Mg}$ and to improve its biocompatibility in the body, a ternary $\mathrm{Mg}$ alloy using $\mathrm{Zn}$ and $\mathrm{Ca}$ as nontoxic and biocompatible alloying elements was prepared. The as-prepared ternary $\mathrm{Mg}$ $\mathrm{Zn}-\mathrm{Ca}$ alloy was subjected to heat treatment followed by artificial aging for different duration of time to alter the microstructure so as to improve the corrosion resistance, biocompatibility, and hemocompatibility.

\section{Materials and Methods}

2.1. Materials. Mg-35Zn-3Ca (wt.\%) alloys were prepared using magnesium (99.93\%, Sincere East Co., China), zinc (99.90\%, Sincere East Co., China), and calcium (99.50\%, Junsei Chemical Co., Ltd., Japan). The experimental alloys were melted in vacuum arc remelting furnace (Ace Vacuum Co., Korea) equipped with water-cooling $\mathrm{Cu}$ hearth. Vacuum arc remelting was performed in presence of argon gas (99.99\%) at $5.0 \times 10^{-5}$ Torr, under a current and voltage of $300 \mathrm{~A}$ and $12 \mathrm{~V}$, respectively. Melting was performed five or more times to prevent segregation and remelting 10 more times while flipping over to obtain homogeneity in $\mathrm{Mg}$-Ca master alloy.
Mg-35Zn-3Ca alloy was manufactured using a vacuum induction melting furnace (Ace Vacuum Co., Korea). Zinc was loaded on the bottom of alumina crucible, and the MgCa master alloy and Mg element were cross-loaded on top of the loaded zinc. The alumina crucible was preheated for $200 \mathrm{~s}$, followed by melting and agitation for $10 \mathrm{~min}$ by increasing the power in an interval of $200 \mathrm{~s}$. The solution was poured into the alumina cast to produce $\mathrm{Mg}-35 \mathrm{Zn}-3 \mathrm{Ca}$ alloy.

For the microstructure observation and assessment of the corrosion resistance of heat treated cast alloy, a $16.4 \mathrm{~mm}$ diameter $\mathrm{Mg}$ stick was sliced into $2 \mathrm{~mm}$ thickness before use.

\subsection{Methods}

2.2.1. Heat Treatment and Artificial Aging. In order to determine the suitable temperature for solution heat treatment, the Mg-35Zn-3Ca alloy specimens were analyzed using Differential Scanning Calorimetry (DSC) (TA Q20, TA Instruments Ltd., USA). Both the Mg-Zn-Ca alloy specimen and reference materials underwent heating/cooling at a constant rate under the same condition. The temperature difference that occurs between the $\mathrm{Mg}-\mathrm{Zn}-\mathrm{Ca}$ alloy specimen and reference material either by exothermic or endothermic reactions was adjusted by supplying the required amount of energy and the transformation temperature was determined by measuring the amount of the supplied energy.

For solution heat treatment, the $\mathrm{Mg}-\mathrm{Zn}-\mathrm{Ca}$ alloy specimens were placed inside an electric arc furnace (Ajeon Industrial Co. Ltd., Korea) and the temperature of the furnace was raised to $310^{\circ} \mathrm{C}$ at a heating rate of $10^{\circ} \mathrm{C} / \mathrm{min}$ and the samples were soaked for $48 \mathrm{~h}$ followed by quenching in distilled water at room temperature. Some of the specimens were subjected to artificial aging following solution heat treatment. For artificial aging, the specimens were placed in an electric arc furnace and the temperature of the furnace was raised to $170^{\circ} \mathrm{C}$ at a heating rate of $10^{\circ} \mathrm{C} / \mathrm{min}$. Then the specimens were soaked for various time intervals from 2.5 to $10.0 \mathrm{~h}$. Specimens which were subjected to only heat treatment at $310^{\circ} \mathrm{C}$ were designated as AT0 whereas those subjected to an additional artificial aging for 2.5, 5.0, 7.5, and $10.0 \mathrm{~h}$ were designated as AT1, AT2, AT3, and AT4, respectively. The details of the experimental conditions employed for heat treatment and artificial aging are compiled in Table 1.

2.2.2. Surface Examination and Analysis. The heat treated and artificially aged $\mathrm{Mg}$ alloy specimens were sequentially polished by $\mathrm{SiC}$ coated abrasive papers (grit size \#800 to \#1600), followed by polishing using $0.3 \mu \mathrm{m} \mathrm{Al}_{2} \mathrm{O}_{3}$ powder and ultrasonic cleaning in distilled water for $5 \mathrm{~min}$. The polished specimens were carefully etched in $2 \%$ Nital etchant (ethanol: $\mathrm{HNO}_{3}=98 \mathrm{~mL}: 2 \mathrm{~mL}$ ) for $5 \mathrm{~s}$ with a periodic assessment of surface microstructure for any sign of acidic corrosion. The microstructure of the $\mathrm{Mg}-\mathrm{Zn}-\mathrm{Ca}$ alloy specimens was examined by scanning electron microscopy (SEM) (JSM-5900, JEOL, Japan) (low magnification images) and by field emission scanning electron microscopy (FESEM) (SUPRA 40VP, Carl Zeiss Co., Ltd., Germany) (high magnification images). In addition, the concentration of the 
TABLE 1: Details of the heat treatment parameters of the Mg-35Za-3Ca alloy.

\begin{tabular}{|c|c|c|c|c|c|}
\hline \multirow{2}{*}{ Type of treatment } & \multicolumn{5}{|c|}{ Group designation and treatment conditions } \\
\hline & AT0 & AT1 & AT2 & AT3 & AT4 \\
\hline Solution treatment & $310^{\circ} \mathrm{C}, 48 \mathrm{~h}$ & $310^{\circ} \mathrm{C}, 48 \mathrm{~h}$ & $310^{\circ} \mathrm{C}, 48 \mathrm{~h}$ & $310^{\circ} \mathrm{C}, 48 \mathrm{~h}$ & $310^{\circ} \mathrm{C}, 48 \mathrm{~h}$ \\
\hline Aging treatment & Untreated & $170^{\circ} \mathrm{C}, 2.5 \mathrm{~h}$ & $170^{\circ} \mathrm{C}, 5.0 \mathrm{~h}$ & $170^{\circ} \mathrm{C}, 7.5 \mathrm{~h}$ & $170^{\circ} \mathrm{C}, 10 \mathrm{~h}$ \\
\hline
\end{tabular}

elements present in the alloy and their distribution were determined using energy dispersive X-ray analysis (EDX) (Oxford, England).

2.2.3. Potentiodynamic Polarization Test. Potentiodynamic polarization test was used to assess the electrochemical corrosion behavior of $\mathrm{Mg}-\mathrm{Zn}-\mathrm{Ca}$ alloy specimens. An electrochemical cell consisting of $\mathrm{Ag} / \mathrm{AgCl}, \mathrm{KCl}$ (sat'd) as the reference electrode, a platinum plate as the counter electrode, and $\mathrm{Mg}-\mathrm{Zn}$-Ca alloy specimens subjected to heat treatment and artificial aging for different duration of time as the working electrode, connected to a potentiostat/galvanostat (273A, EG\&G, PARC, USA), was used for the study. The experiments were performed with exposing the area $1 \mathrm{~cm}^{2}$ in $150 \mathrm{~mL}$ of Hanks solution, whose chemical composition is presented in Table 2 . The potentiodynamic polarization test was performed in the potential range $-0.5 \mathrm{~V}$ to $+0.5 \mathrm{~V}$ at a scan rate of $3 \mathrm{mV} / \mathrm{s}$ at room temperature. The corrosion potential $\left(E_{\text {corr }}\right)$ and current density $\left(i_{\text {corr }}\right)$ were calculated from the measured polarization curves using Tafel extrapolation method, followed by assessment of extent of corrosion the specimens.

2.2.4. Immersion Test. The initial $\mathrm{pH}$ of the HBSS was adjusted to 7.2 with the incremental additions of either $\mathrm{NaOH}(0.1 \mathrm{~mol} / \mathrm{L})$ or $\mathrm{HCl}(0.1 \mathrm{~mol} / \mathrm{L})$ using a $\mathrm{pH}$ meter $(\mathrm{HD}-$ $\mathrm{PH} / \mathrm{P}$, Davis Co. Ltd., USA). The Mg-Zn-Ca alloy specimens subjected to heat treatment and artificial aging for different duration of time were immersed in $45 \mathrm{~mL}$ of HBSS and incubated at $37^{\circ} \mathrm{C}$ for $72 \mathrm{~h}$. The change in $\mathrm{pH}$ of the HBSS was measured as a function of immersion time.

2.2.5. Measurement of Corrosion Rate. The Mg-Zn-Ca alloy specimens subjected to heat treatment and artificial aging for different duration of time were immersed in $45 \mathrm{~mL}$ of HBSS and incubated at $37^{\circ} \mathrm{C}$ for 5 days. The HBSS was replaced every $24 \mathrm{~h}$ to suppress the change in concentration of the solution during the test. After 5 days of immersion, the $\mathrm{Mg}$ alloy specimens were rinsed in deionized water and ultrasonically cleaned using isopropanol for $5 \mathrm{~min}$ to remove the corrosion products attached to the specimen. The specimens were washed with distilled water and then dried. To examine weight changes in the specimen caused by corrosion, the specimen weight was measured before and 5 days after deposition. The corrosion rate was calculated using the following equation [23]:

$$
C_{R}=\frac{W}{A \times t}
$$

TABLE 2: Chemical composition of Hank's balanced salt solution (HBSS).

\begin{tabular}{lc}
\hline Constituents & Quantity $(\mathrm{g} / \mathrm{L})$ \\
\hline Potassium phosphate monobasic [anhydrous] & 0.06 \\
Sodium phosphate dibasic [anhydrous] & 0.04788 \\
Potassium chloride & 0.4 \\
Sodium chloride & 8.0 \\
Phenol red Na & 0.011 \\
D-Glucose & 1.0 \\
\hline
\end{tabular}

where $C_{R}$ is corrosion rate, $W$ is weight loss, $A$ is surface area of the specimen exposed to the etching reagent, and $t$ is exposure time.

2.2.6. Hemolysis Assessment. The test solution used for hemolysis assessment was blood samples collected from the coronary artery of rats, which were treated with heparin and diluted with saline solution in a 4:5 ratio (vol.\%). Specimens having a dimensions of $16.4 \mathrm{~mm}$ diameter and $2 \mathrm{~mm}$ thickness from each experimental group were treated with $10 \mathrm{~mL}$ of saline solution for $30 \mathrm{~min}$ and the elute was used as the experimental group. $10 \mathrm{~mL}$ saline solution containing 0.1 wt. $\%$ of $\mathrm{Na}_{2} \mathrm{CO}_{3}$ and $10 \mathrm{~mL}$ saline solution were used as the positive and negative control groups, respectively. Each $10 \mathrm{~mL}$ solution of each group (experimental group and the positive and negative control group) was mixed with $0.2 \mathrm{~mL}$ of the prepared test solution and incubated at $37^{\circ} \mathrm{C}$ for $60 \mathrm{~min}$. Subsequently, each mixture was centrifuged at $680 \mathrm{G}$ for $3 \mathrm{~min}$, and $200 \mu \mathrm{L}$ of the supernatant liquid was collected. Then absorbance was measured at $540 \mathrm{~nm}$ using a medical enzyme analyzer (Emax, Molecular Devices, USA). The measured absorbance was used to assess the percentage hemolysis by the following equation [24]:

$$
\text { hemolysis }(\%)=\frac{\mathrm{OD}(\text { test })-\mathrm{OD}(\text { negative })}{\mathrm{OD}(\text { positive })-\mathrm{OD}(\text { negative })} \times 100 \text {. }
$$

\section{Results}

The SEM image of the microstructure of the as-cast Mg$35 \mathrm{Zn}-3 \mathrm{Ca}$ alloy etched using Nital for $5 \mathrm{~s}$ and its chemical composition analyzed by EDX analysis are shown in Figure 1. The microstructure of the alloy is homogeneous and reveals no casting defects. The chemical composition of the alloy indicates the presence of $\mathrm{Mg}$ (63.82 wt.\%), $\mathrm{Zn}$ (32.63 wt.\%), 




(a)

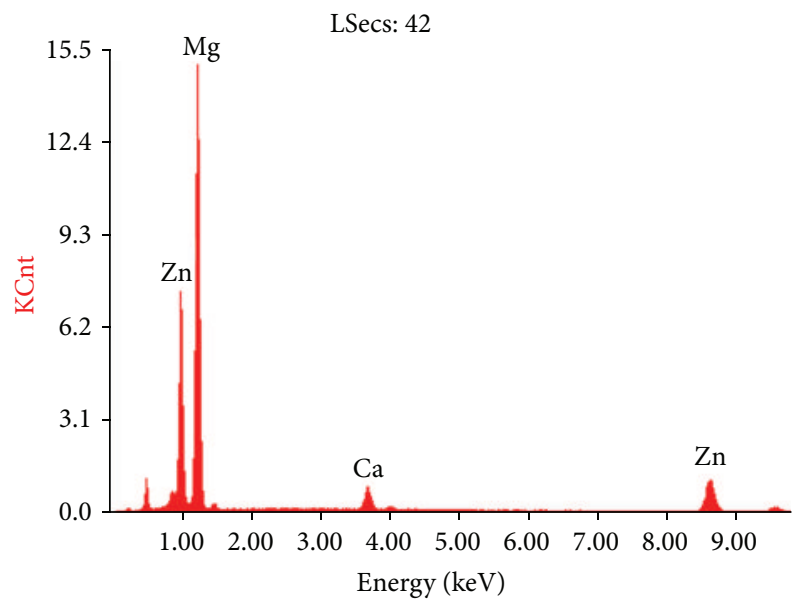

(b)

FIGURE 1: SEM micrograph of as-cast Mg-35Zn-3Ca (a) and EDX spectrum results (b).

TABLE 3: Elemental composition of Mg-35Zn-3Ca alloy assessed by energy dispersive $\mathrm{X}$-ray analysis.

\begin{tabular}{lcc}
\hline & Atomic \% & Weight \% \\
\hline $\mathrm{Ca}$ & 2.76 & 3.55 \\
$\mathrm{Zn}$ & 15.54 & 32.63 \\
$\mathrm{Mg}$ & Balance & Balance \\
\hline
\end{tabular}

and $\mathrm{Ca}(3.55$ wt.\%) as the major elements (Table 3), suggesting that the alloy conforms to the chemical composition requirements of $\mathrm{Mg}-35 \mathrm{Zn}-3 \mathrm{Ca}$ alloy.

The DSC trace of the as-cast Mg-35Zn-3Ca alloy specimen is shown in Figure 2. The liquidus and solidus temperatures are $361.84^{\circ} \mathrm{C}$ and $340.11^{\circ} \mathrm{C}$, respectively. Based on this result, the suitable temperature for solution heat treatment is set as $310^{\circ} \mathrm{C}$, which is slightly lower than the solidus temperature of the alloy. Accordingly, the as-cast Mg-35Zn-3Ca alloy is homogenized at $310^{\circ} \mathrm{C}$ for $48 \mathrm{~h}$ and quenched in deionized water at room temperature to prevent any microsegregation and residual stress during precipitation (designated as AT0). Some of the specimens were subjected to artificial aging heat treatment at $170^{\circ} \mathrm{C}$ for $2.5,5.0,7.5$, and $10.0 \mathrm{~h}$ and designated as AT1, AT2, AT3, and AT4, respectively.

The SEM images of the surface microstructure of the heat-treated (AT0) and artificially aged (AT1, AT2, AT3, and AT4) Mg-35Zn-3Ca alloy specimens, etched in Nital for $5 \mathrm{~s}$, are shown in Figure 3. Among all the specimens, the AT2 group exhibits the finest and most homogenous distribution of $\alpha$ and $\beta$ phases. It is also evident from Figure 3 that, with increase in aging time, the size of $\alpha$ phase is increased with the disappearance of the boundary of $\beta$ phase, resulting in a change in microstructure from a homogeneous to an inhomogeneous state. The X-ray elemental mapping of $\mathrm{Mg}$, $\mathrm{Zn}$, and $\mathrm{Ca}$ along with the secondary electron image of the $\mathrm{Mg}-35 \mathrm{Zn}-3 \mathrm{Ca}$ alloy is shown in Figure 4. It is evident that the darker regions of the microstructure are mostly the $\alpha-\mathrm{Mg}$ matrix whereas the lighter regions are mainly the

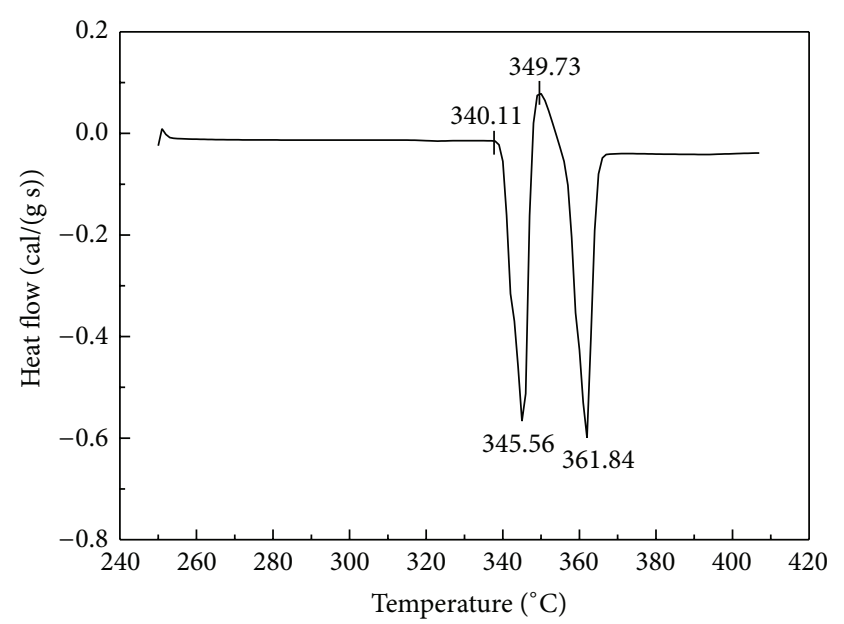

FIGURE 2: DSC thermogram (heating curve) of as-cast Mg-35Zn3Ca alloy.

$\beta$-phase precipitate, which are relatively lower in $\mathrm{Mg}$ and largely consist of zinc and calcium.

The potentiodynamic polarization curves of heat-treated (AT0) and artificially aged (AT1, AT2, AT3, and AT4) Mg$35 \mathrm{Zn}-3 \mathrm{Ca}$ alloy specimens in HBSS are shown in Figure 5. The $E_{\text {corr }}$ and $i_{\text {corr }}$ values of all the specimens, calculated using Tafel extrapolation method, are compiled in Table 4. There is not much variation in the $E_{\text {corr }}$ of all the specimens tested and all of them lie in the range of -1.20 to $-1.29 \mathrm{~V}$ versus $\mathrm{Ag} / \mathrm{AgCl} / \mathrm{KCl}$ (sat'd). The $i_{\text {corr }}$ values of the specimens that are heat-treated and artificially aged for different duration of time (AT1 to AT4) are relatively higher than those subjected only for heat treatment (AT0). Among the heat treated and artificially aged samples (AT1 to AT4), specimens of the AT2 group exhibit a lower $i_{\text {corr }}$. Based on the $i_{\text {corr }}$ values, the corrosion resistance of the $\mathrm{Mg}-35 \mathrm{Zn}-3 \mathrm{Ca}$ alloys specimens subjected to only heat treatment (AT0) and heat treatment followed by artificial aging for different duration of time (AT1 to AT4) can be ranked as follows: AT0 $>$ AT2 $>$ AT3 $>$ AT4 $>$ AT1. 


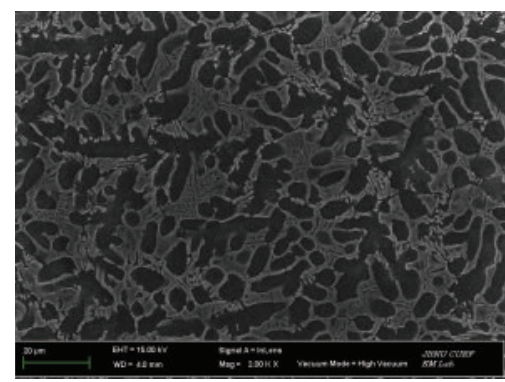

(a)

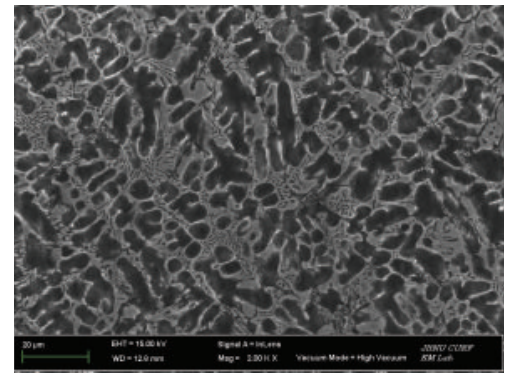

(d)

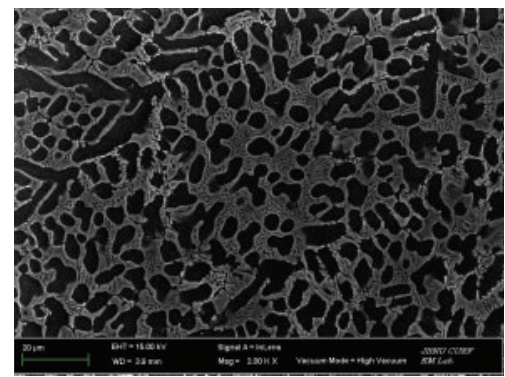

(g)

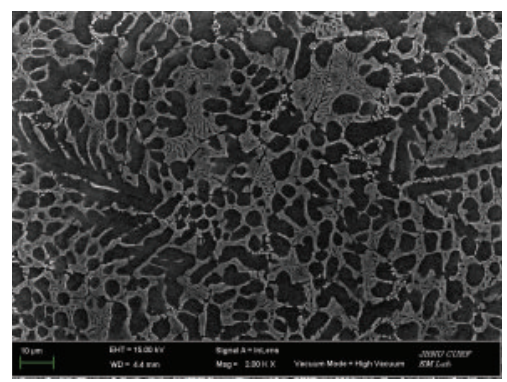

(j)

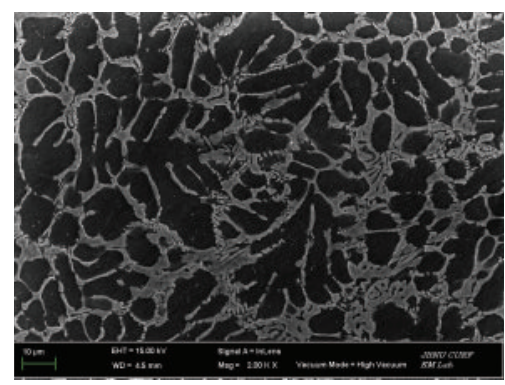

(m)

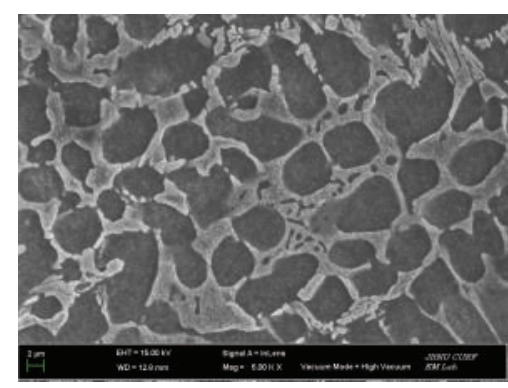

(b)

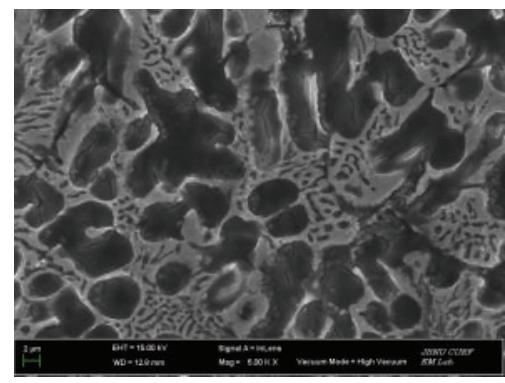

(e)

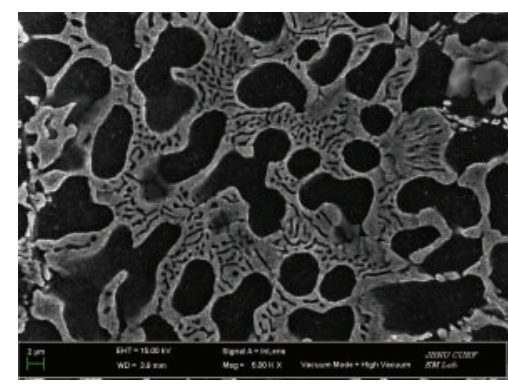

(h)

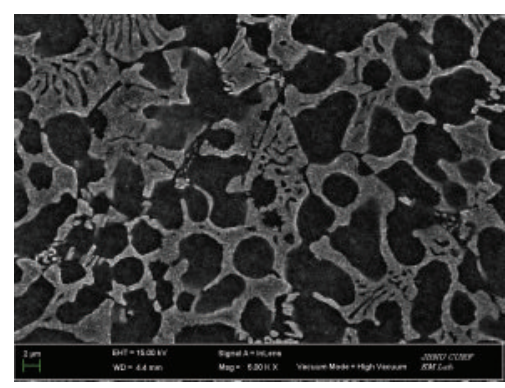

(k)

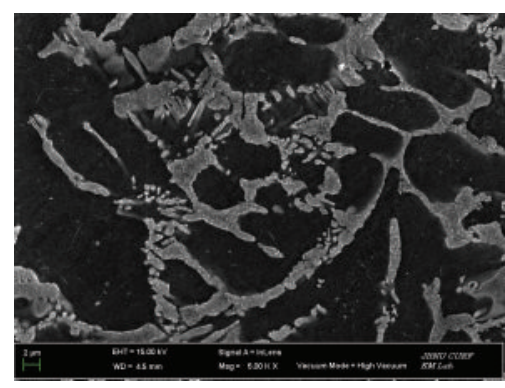

(n)

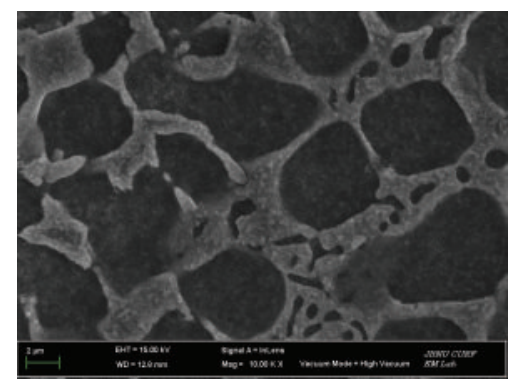

(c)

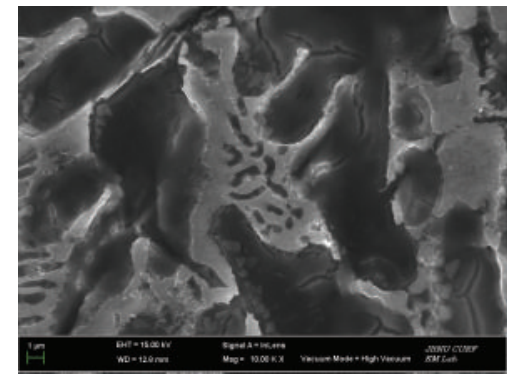

(f)

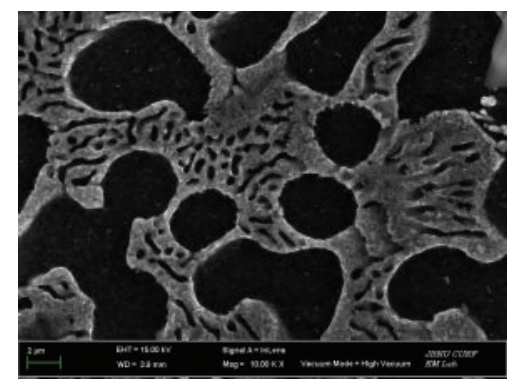

(i)



(1)

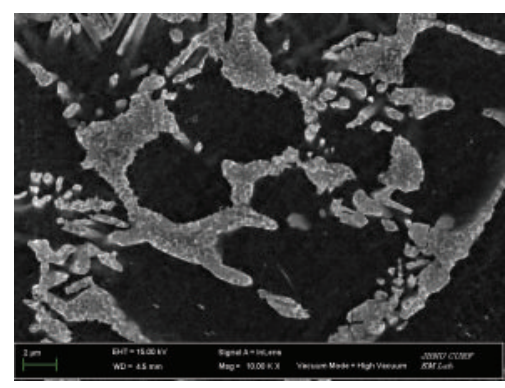

(o)

FIGURE 3: Surface morphology of various heat treated Mg-35Zn-3Ca alloys: (a) AT0 ( $\times 2000)$, (b) AT0 ( $\times 5000),($ c) AT0 ( $\times 10000)$, (d) AT1 (×2000), (e) AT1 (×5000), (f) AT1 (×10000), (g) AT2 (×2000), (h) AT2 (×5000), (i) AT2 (×10000), (j) AT3 (×2000), (k) AT3 (×5000), (l) AT3 $(\times 10000),(\mathrm{m})$ AT4 $(\times 2000),(\mathrm{n})$ AT4 $(\times 5000)$, and $(\mathrm{o})$ AT4 $(\times 10000)$. 
TABLE 4: Electrochemical corrosion parameters of Mg-35Zn-3Ca alloy in HBSS, derived from the potentiodynamic polarization test using Tafel extrapolation method.

\begin{tabular}{|c|c|c|c|c|c|}
\hline & \multicolumn{5}{|c|}{ Group } \\
\hline & AT0 & AT1 & AT2 & AT3 & AT4 \\
\hline$E_{\text {corr }}(\mathrm{V}$ vs $\mathrm{Ag} / \mathrm{AgCl} / \mathrm{KCl}$ (sat'd) $)$ & -1.29 & -1.23 & -1.23 & -1.20 & -1.23 \\
\hline$i_{\text {corr }}\left(\mu \mathrm{A} / \mathrm{cm}^{2}\right)$ & 1.011 & 5.091 & 3.641 & 3.751 & 4.908 \\
\hline
\end{tabular}
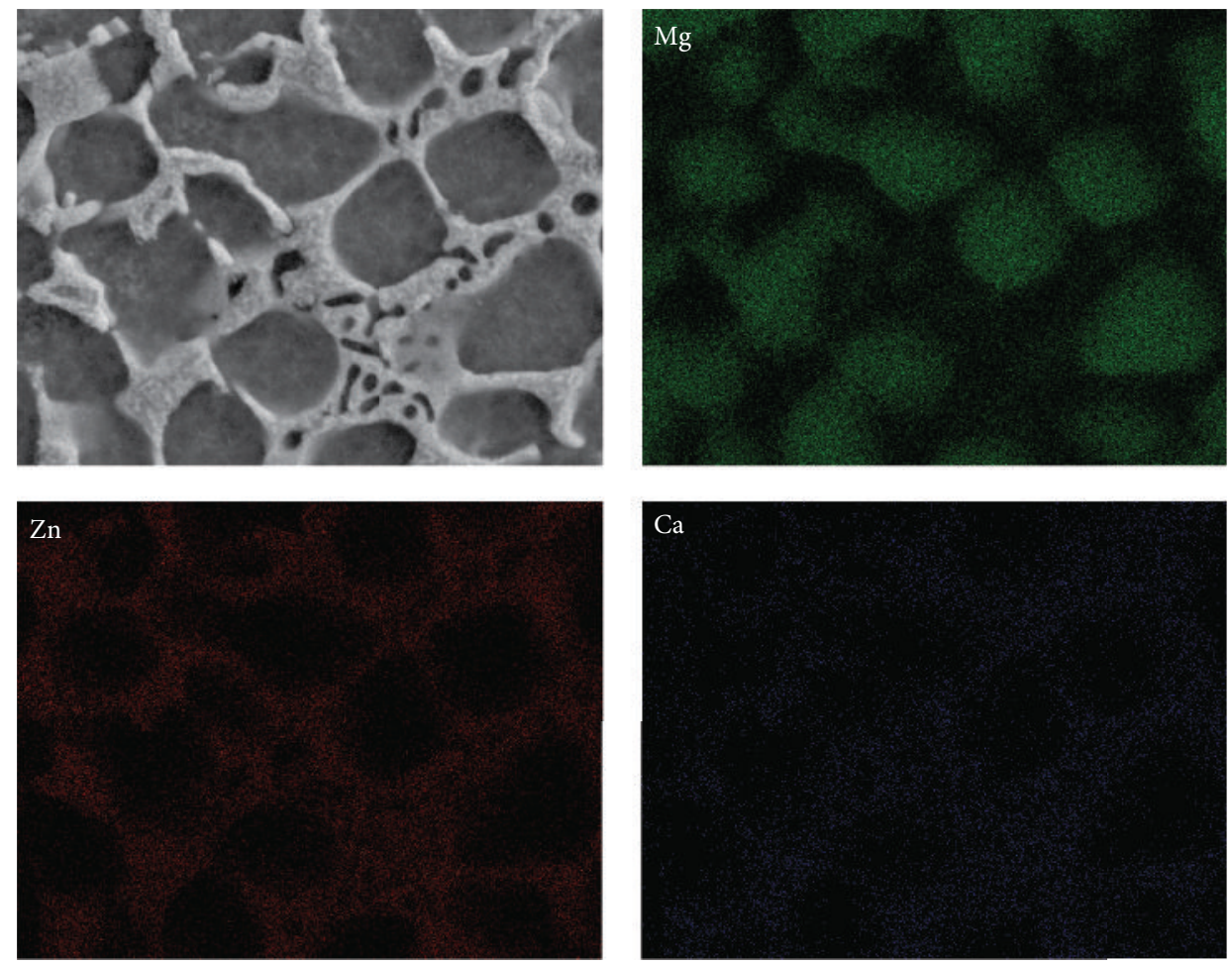

Figure 4: Analysis of elemental composition on the surface by EDX mapping of Mg-35Zn-3Ca alloy.

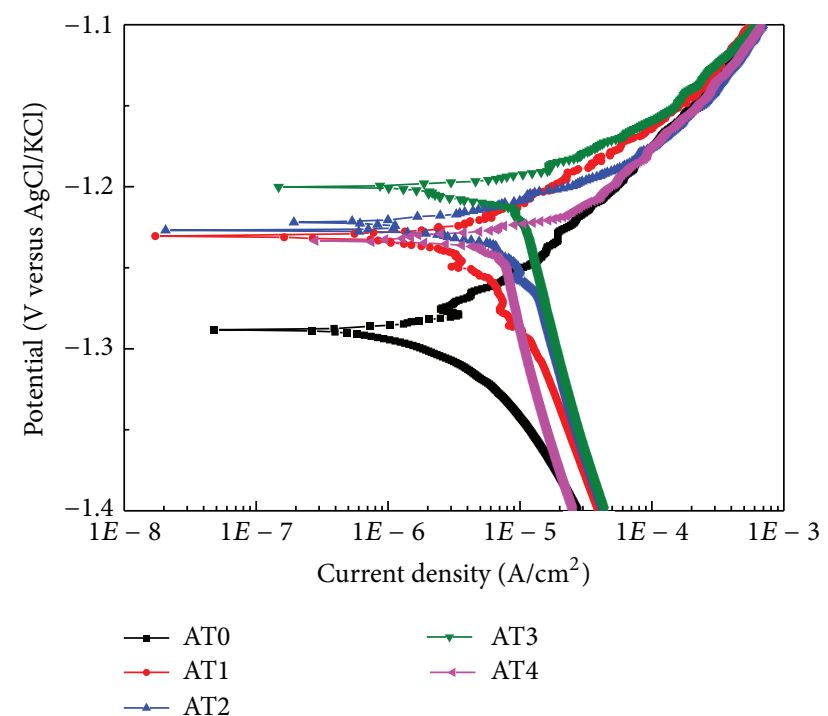

FIGURE 5: Potentiodynamic polarization curve obtained in HBSS: various heat treated $\mathrm{Mg}-35 \mathrm{Zn}-3 \mathrm{Ca}$ alloys.
The change in $\mathrm{pH}$ of the HBSS in which the Mg-35Zn$3 \mathrm{Ca}$ alloys subjected to only heat treatment (AT0) and heat treatment followed by artificial aging for different durations (AT1 to AT4) are immersed, measured for a duration of $72 \mathrm{~h}$, is shown in Figure 6. In general, all the specimens exhibit a rapid increase in $\mathrm{pH}$ during the first $6 \mathrm{~h}$, beyond which the extent of increase in $\mathrm{pH}$ is decreased. Beyond $48 \mathrm{~h}$ of immersion the $\mathrm{pH}$ of HBSS reached a stable value for all the specimens studied. During the first $6 \mathrm{~h}$ of immersion, the $\mathrm{Mg}$ 35Zn-3Ca alloy specimens subjected to heat treatment alone (AT0) showed a rapid increase in $\mathrm{pH}$ when compared to those subjected to heat treatment followed by artificial aging for different duration of time (AT1 to AT4). Among the AT1 to AT4 group, specimens of the AT2 group showed a relatively less increase in $\mathrm{pH}$, suggesting the lower extent of dissolution of the $\mathrm{Mg}$ alloy.

The corrosion rate of the $\mathrm{Mg}-35 \mathrm{Zn}-3 \mathrm{Ca}$ alloy specimens subjected to only heat treatment (AT0) and heat treatment followed by artificial aging for different duration of time (AT1 to AT4), calculated using the loss in weight after immersion in $\mathrm{HBSS}$ at $37^{\circ} \mathrm{C}$ for 5 days, is shown in Figure 7. It is evident 


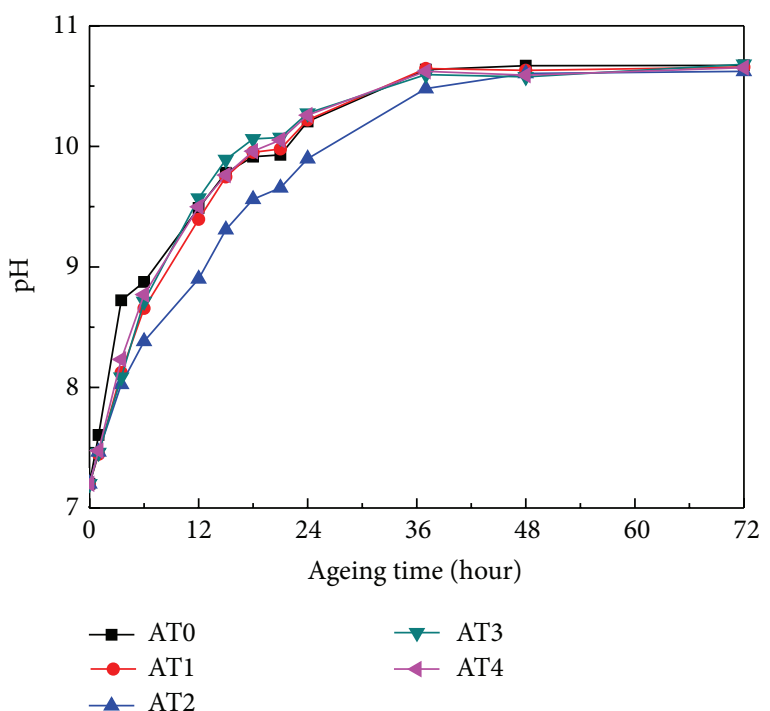

FIGURE 6: $\mathrm{pH}$ value as a function of immersion time.

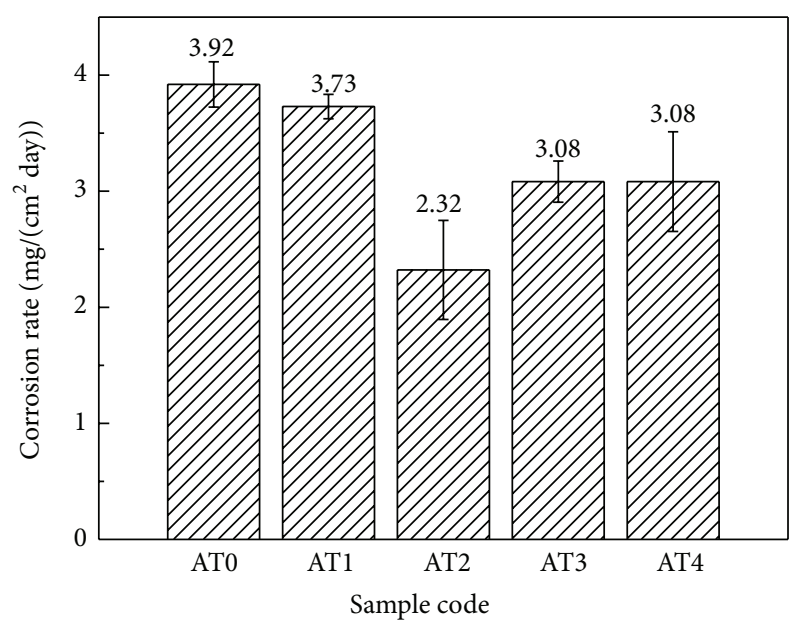

FIgURE 7: Corrosion rates of different heat treated $\mathrm{Mg}-35 \mathrm{Zn}-3 \mathrm{Ca}$ alloys after immersion in HBSS for 5 days.

that specimens subjected to heat treatment alone (AT0) show a higher corrosion rate $\left(3.92 \mathrm{mg} /\left(\mathrm{cm}^{2}\right.\right.$ day $\left.)\right)$ when compared to those subjected to heat treatment followed by artificial aging for different durations (AT1 to AT4) (ranging from 2.32 to $3.73 \mathrm{mg} /\left(\mathrm{cm}^{2}\right.$ day $\left.)\right)$. Among the AT1 to AT4 group, specimens of the AT2 group showed a lower corrosion rate of $2.32 \mathrm{mg} /\left(\mathrm{cm}^{2}\right.$ day $)$, which is significantly lower than those of other groups $(P<0.05)$.

In vitro hemolysis test is a well-known method to assess the biotoxicity in a short duration of time. The hemolysis ability of $\mathrm{Mg}-35 \mathrm{Zn}-3 \mathrm{Ca}$ alloy specimens subjected to only heat treatment (AT0) and, heat treatment followed by artificial aging for different duration of time (AT1 to AT4), is measured using the positive $(10 \mathrm{~mL}$ saline solution containing $0.1 \mathrm{wt} . \%$ of $\mathrm{Na}_{2} \mathrm{CO}_{3}$ ) and negative (10 $\mathrm{mL}$ saline solution) as controls. The measured optical density values and the \%
TABLE 5: Absorbance value measured at $540 \mathrm{~nm}$ and percentage of hemolysis of $\mathrm{Mg}-35 \mathrm{Zn}-3 \mathrm{Ca}$ alloy subjected to heat treatment and artificial aging for different duration of time.

\begin{tabular}{lcc}
\hline Sample code & OD at $540 \mathrm{~nm}$ & Hemolysis $(\%)$ \\
\hline AT0 & $0.051 \pm 0.002$ & $0.515 \pm 0.375$ \\
AT1 & $0.050 \pm 0.002$ & $0.371 \pm 0.204$ \\
AT2 & $0.049 \pm 0.001$ & $0.147 \pm 0.104$ \\
AT3 & $0.050 \pm 0.001$ & $0.299 \pm 0.275$ \\
AT4 & $0.051 \pm 0.002$ & $0.521 \pm 0.272$ \\
Negative & $0.049 \pm 0.001$ & 0 \\
Positive & $0.495 \pm 0.013$ & 100 \\
\hline
\end{tabular}

hemolysis are compiled in Table 5. The variation in the \% hemolysis of all the samples tested along with the negative and positive controls is plotted in Figure 8 for a better comparison and to understand the statistical difference among them. It is evident from Table 5 and Figure 8 that among all the specimens tested those belonging to the AT2 group showed the lowest value of $\%$ hemolysis $(0.147 \%)$. However, when compared to other groups, the difference in \% hemolysis is statistically insignificant $(P>0.05)$.

\section{Discussion}

$\mathrm{Mg}$ undergoes rapid corrosion in electrolytes containing chlorides, such as body fluid. Hence, it will be difficult to use $\mathrm{Mg}$ for implant applications. When $\mathrm{Mg}$ is exposed to air, the oxide layer formed on its surface offers only a partial protection. In aqueous solution, the formation of porous $\mathrm{Mg}(\mathrm{OH})_{2}$ layer could not offer much protection (equation (3)). In presence of chloride ions, it gets dissolved as $\mathrm{MgCl}_{2}$ while the aggressive nature of the medium causes severe corrosion of the $\mathrm{Mg}$ (equations (4) and (5)) [25]. The reaction sequences of $\mathrm{Mg}$ in aqueous medium in the absence (equation (3)) and presence (equations (4) and (5)) of chloride ions can be represented as follows [8]:

$$
\begin{gathered}
\mathrm{Mg}(\text { solid })+2 \mathrm{H}_{2} \mathrm{O} \longrightarrow \mathrm{Mg}(\mathrm{OH})_{2}+\mathrm{H}_{2} \text { (gas) } \\
\mathrm{Mg}(\text { solid })+2 \mathrm{Cl}^{-} \text {(aqueous) } \longrightarrow \mathrm{MgCl}_{2} \\
\mathrm{Mg}(\mathrm{OH})_{2} \text { (solid) }+2 \mathrm{Cl}^{-} \longrightarrow \mathrm{MgCl}_{2} .
\end{gathered}
$$

The corrosion resistance of $\mathrm{Mg}$ could be improved through alloying, formation of composites, surface treatment, and heat treatment [25-31]. However, the alloying elements, the second phase materials used to prepare the composites, and the surface treated layer should not be harmful to the body when used as a biomaterial. Some of the commonly used Mg-based alloys contain aluminum that is harmful to the nervous system and osteoblasts while the RE-based $\mathrm{Mg}$ alloys could cause blood toxicity [17, 18]. In the present study, $\mathrm{Mg}-35 \mathrm{Zn}-3 \mathrm{Ca}$ alloy is prepared by adding zinc and calcium as alloying elements, both of which are nontoxic. Alloying magnesium with zinc enables precipitation hardening while alloying with calcium could help in grain refinement. The microstructure and corrosion 


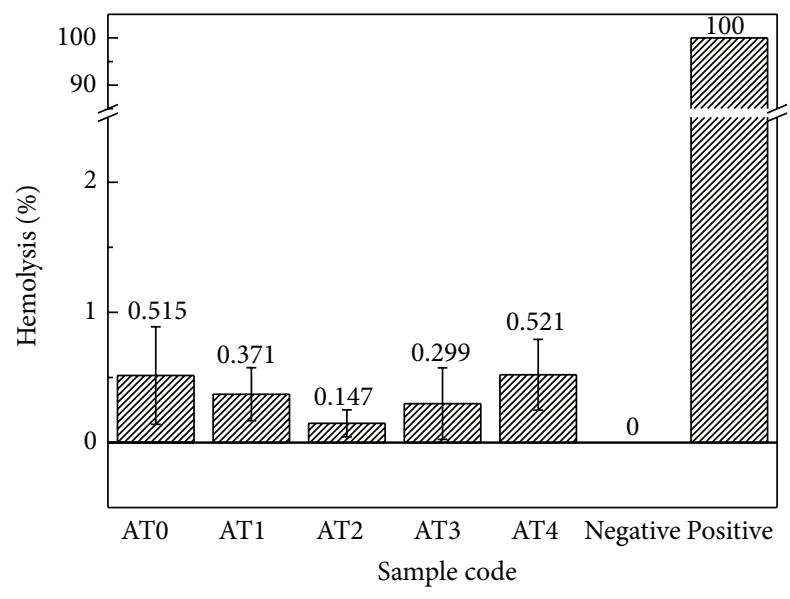

FIGURE 8: Hemolysis percentage of various heat treated Mg-35Zn3Ca alloys.

resistance of the $\mathrm{Mg}-35 \mathrm{Zn}-3 \mathrm{Ca}$ alloy are evaluated after subjecting them to only heat treatment (AT0) and heat treatment and artificial aging for different duration of time (AT1 to AT4).

The microstructural examination after solution heat treatment and artificial aging heat treatment performed over a specific period of time showed that the $\alpha$ and $\beta$ phases were finest and most homogenous in the AT2 group, which underwent an artificial aging heat treatment at $170^{\circ} \mathrm{C}$ for $5 \mathrm{~h}$. Moreover, the grain boundary was broken and $\beta$ phase was inhomogeneous in the AT3 group, which underwent artificial aging heat treatment for $7.5 \mathrm{~h}$. Results also showed that the size of crystal grain became larger and the continuity of the crystal margin has disappeared in the AT4 group, which underwent artificial aging heat treatment for $10 \mathrm{~h}$ (Figure 3). Solution heat treatment is a process to prepare the supersaturated solid solution of unstable state; materials are generally softened by solution heat treatment. Previous studies have reported that artificial aging heat treatment following solution heat treatment of $\mathrm{Mg}$ alloy improved strength by refinement of the precipitate [29]. Meanwhile, it was reported that heat treatment changed the microstructure of alloy thereby affecting the corrosion behavior $[32,33]$.

In this study, potentiodynamic polarization studies, change in $\mathrm{pH}$ of HBSS, and loss in weight after immersion in HBSS were used to assess the corrosion resistance of the Mg-35Zn-3Ca alloy, both in as-prepared and heat-treated conditions. The results of the potentiodynamic polarization test, conducted to assess electrochemical corrosion behavior, showed the lowest corrosion current density of $1.011 \mu \mathrm{A} / \mathrm{cm}^{2}$ for the AT0 group, which underwent only the solution heat treatment. Among the groups that underwent artificial aging following solution heat treatment, the lowest corrosion current density of $3.641 \mu \mathrm{A} / \mathrm{cm}^{2}$ is observed for the AT2 group. The corrosion current density, which is closely associated with corrosion rate, is an intersection point at which the negative Tafel slope is extrapolated to corrosion potential by the Tafel extrapolation method [34]. This result showed that corrosion resistance of the $\mathrm{Mg}-35 \mathrm{Zn}-3 \mathrm{Ca}$ alloy is much improved for the group that underwent solution heat treatment alone than in groups that underwent artificial aging heat treatment following solution heat treatment. When immersed in HBSS, Mg undergoes anodic dissolution with the release of $\mathrm{H}_{2}$ gas and generation of $\mathrm{OH}^{-}$ions, resulting in an increase in $\mathrm{pH}$ of the medium [35]. These reaction sequences can be represented as follows [36]:

$$
\begin{gathered}
\text { Anodic reaction: } \mathrm{Mg} \longrightarrow \mathrm{Mg}^{2+}+2 \mathrm{e} \\
\text { Cathodic reaction: } 2 \mathrm{H}_{2} \mathrm{O}+2 \mathrm{e} \longrightarrow \mathrm{H}_{2}+2 \mathrm{OH}^{-} \\
\text {Formation of corrosion product: } \\
\mathrm{Mg}^{2+}+2 \mathrm{OH}^{-} \longrightarrow \mathrm{Mg}(\mathrm{OH})_{2} .
\end{gathered}
$$

Thus, the rate of corrosion of $\mathrm{Mg} / \mathrm{Mg}$ alloys could be estimated from the change in $\mathrm{pH}$ of the corrosive medium (HBSS in this study) as a function of time. The change in $\mathrm{pH}$ of the HBSS measured as a function of time (Figure 6) showed that it is slowest for specimens in the T2 group when compared to other groups. This inference indicates that the corrosion resistance is increased as the microstructure of the surface gets finer and denser. The loss in weight of the specimens measured after 5 days of immersion in HBSS is $2.32 \mathrm{mg} /\left(\mathrm{cm}^{2}\right.$ day) for the AT2 group, which is significantly lower than that of the other groups $(P<0.05)$. The loss in weight is $3.92 \mathrm{mg} /\left(\mathrm{cm}^{2}\right.$ day $)$ for the AT0 group, which is the highest among all the specimens tested. However, the difference between the specimens is insignificant when compared with the specimens in other groups except with the AT2 group $(P>0.05)$. Hence, it is clear that the specimens of the AT2 group have offered an excellent corrosion resistance, which is consistent with the results of change in $\mathrm{pH}$. However, the results are inconsistent with those of the potentiodynamic polarization test. The fineness and homogeneity of the $\beta$ phase largely determine the corrosion behavior, which is reflected in the $\mathrm{pH}$ variation and weight loss. These results supported that corrosion behavior of magnesium alloys with multiphase structure is changed according to corrosion potential difference, distribution, and volume fraction between micr-constituent phases [16, 37, 38]. Since these measurements are made for a long term, the ability of the $\beta$ phase to act as a physical barrier for corrosion becomes effective [33, 39]. However, during the electrochemical study, since the test is performed over a short duration, the effect is not reflected [29].

The hemolysis test, which is conducted to assess the toxicity to the body, uses the principle that red blood cells are divided or necrotized when the hemoglobin is destroyed. The concentration of free hemoglobin is proportional to the number of the injured RBC and the volume of the fluid [24, 40]. The results of hemolysis test showed that the percentage of hemolysis $(0.147 \%)$ in AT2 group is the lowest among all the samples tested and when compared with other groups, no statistical significance difference could be observed (Figure 8, Table 5) $(P>0.05)$. In general, if the hemolysis value is $5 \%$ or less, then it is considered as nonhemolytic according to 
ISO 10993-4:2002 [41]. Accordingly, the composition of Mg35Zn-3Ca has low hemolysis and analogies good biocompatibility. In other words, homogenization and aging process of the $\mathrm{Mg}-35 \mathrm{Zn}-3 \mathrm{Ca}$ alloy can improve the physical properties and corrosion resistance of the material and it does not have a significant effect on the hemolytic toxicity.

\section{Conclusions}

The preparation of $\mathrm{Mg}-35 \mathrm{Zn}-3 \mathrm{Ca}$ alloy containing zinc and calcium, rather than aluminum or RE elements, as nontoxic and biocompatible alloying elements, followed by heat treatment and artificial aging of the alloy to control its rate of degradation, is reported. The study leads to the following conclusions.

(1) DSC studies showed that the liquidus and solidus temperatures of the $\mathrm{Mg}-35 \mathrm{Zn}-3 \mathrm{Ca}$ alloy were $361.84^{\circ} \mathrm{C}$ and $340.11^{\circ} \mathrm{C}$, respectively.

(2) The microstructural features of the $\mathrm{Mg}-35 \mathrm{Zn}-3 \mathrm{Ca}$ alloy indicate the presence of $\alpha-\mathrm{Mg}$ matrix and $\beta$ phase after heat treatment and artificial aging for various duration of time. Among them, the AT2 group (heat treatment at $170^{\circ} \mathrm{C}$ for $5 \mathrm{~h}$ followed by artificial aging at $310^{\circ} \mathrm{C}$ for $48 \mathrm{~h}$ ) exhibits the finest and most homogenous distribution of $\alpha$ and $\beta$ phases.

(3) Potentiodynamic polarization studies of the $\mathrm{Mg}$ $35 \mathrm{Zn}-3 \mathrm{Ca}$ alloy specimens indicate that the $i_{\text {corr }}$ values of specimens that are heat-treated and artificially aged for different duration of time (AT1 to AT4) are relatively higher than those subjected only to heat treatment (AT0). Among heat-treated and artificially aged samples (AT1 to AT4), specimens of the AT2 group exhibit a lower $i_{\text {corr }}$. Based on the $i_{\text {corr }}$ values, the specimens can be ranked as follows: AT0 > AT2 > AT3 $>$ AT4 $>$ AT1.

(4) The change in $\mathrm{pH}$ of the HBSS measured for $72 \mathrm{~h}$ indicates that all the specimens exhibit a rapid increase in $\mathrm{pH}$ during the first $6 \mathrm{~h}$, during which the Mg-35Zn$3 \mathrm{Ca}$ alloy specimens subjected to heat treatment alone (AT0) showed a rapid increase in $\mathrm{pH}$. Beyond $48 \mathrm{~h}$ of immersion the $\mathrm{pH}$ of HBSS reached a stable value for all the specimens studied. Among the AT1 to AT4 groups, specimens of the AT2 group showed a relatively less increase in $\mathrm{pH}$, suggesting the lower extent of dissolution of the $\mathrm{Mg}$ alloy.

(5) Mg-35Zn-3Ca alloy specimens subjected to heat treatment alone (AT0) showed a corrosion rate of $3.92 \mathrm{mg} /\left(\mathrm{cm}^{2}\right.$ day $)$ than those subjected to heat treatment followed by artificial aging for different durations (AT1 to AT4), which ranges between 2.32 and $3.73 \mathrm{mg} /\left(\mathrm{cm}^{2}\right.$ day $)$. Among the AT1 to AT4 groups, specimens of the AT2 group showed a lower corrosion rate of $2.32 \mathrm{mg} /\left(\mathrm{cm}^{2}\right.$ day), which is significantly lower than those of other groups $(P<0.05)$.

(6) In vitro hemolysis test showed the lowest hemolysis percentage value of $0.147 \%$ for the AT2 group, but the differences were statistically insignificant when compared with that of other groups $(P<0.05)$. The hemolysis was $5 \%$ or less for all groups, which indicates no significant hemoglobin destruction, which suggests that Mg-35Zn-3Ca alloy has no cytotoxicity.

\section{Conflict of Interests}

The authors declare that there is no conflict of interests regarding the publication of this paper.

\section{Authors' Contribution}

Il-Song Park contributed to this work and is considered as joint first author.

\section{Acknowledgments}

This work was supported by the National Research Foundation of Korea (NRF) Grant funded by the Korea government (MSIP) (no. 2011-0028709 and no. 2014R1A4A1005309) and Regional Strategic Industry project (2013-R0002274).

\section{References}

[1] D. A. Puleo and W. W. Huh, "Acute toxicity of metal ions in cultures of osteogenic cells derived from bone marrow stromal cells," Journal of Applied Biomaterials, vol. 6, no. 2, pp. 109-116, 1995.

[2] J. J. Jacobs, J. L. Gilbert, and R. M. Urban, "Current concepts review. Corrosion of metal orthopaedic implants," The Journal of Bone \& Joint Surgery, vol. 80, pp. 268-282, 1998.

[3] C. Lhotka, T. Szekeres, I. Steffan, K. Zhuber, and K. Zweymüller, "Four-year study of cobalt and chromium blood levels in patients managed with two different metal-on-metal total hip replacements," Journal of Orthopaedic Research, vol. 21, no. 2, pp. 189-195, 2003.

[4] J. J. Jacobs, A. K. Skipor, L. M. Patterson et al., "Metal release in patients who have had a primary total hip arthroplasty. A prospective, controlled, longitudinal study," The Journal of Bone and Joint Surgery-American Volume, vol. 80, no. 10, pp. 1447$1458,1998$.

[5] J. J. Jacobs, N. J. Hallab, A. K. Skipor, and R. M. Urban, "Metal degradation products: a cause for concern in metalmetal bearings?" Clinical Orthopaedics and Related Research, no. 417, pp. 139-147, 2003.

[6] J. Nagels, M. Stokdijk, and P. M. Rozing, "Stress shielding and bone resorption in shoulder arthroplasty," Journal of Shoulder and Elbow Surgery, vol. 12, no. 1, pp. 35-39, 2003.

[7] H. G. Seiler, H. Sigel, and A. Sigel, Handbook on Toxicity of Inorganic Compounds, 1988.

[8] M. P. Staiger, A. M. Pietak, J. Huadmai, and G. Dias, "Magnesium and its alloys as orthopedic biomaterials: a review," Biomaterials, vol. 27, no. 9, pp. 1728-1734, 2006.

[9] E. P. DeGarmo, J. T. Black, and R. A. Kohser, DeGarmo's Materials and Processes in Manufacturing, John Wiley \& Sons, 2011.

[10] L. J. Gibson and M. F. Ashby, Cellular Solids: Structure and Properties, Cambridge University Press, 1999. 
[11] J.-W. Choi, Y.-M. Kong, H.-E. Kim, and I.-S. Lee, "Reinforcement of hydroxyapatite bioceramic by addition of $\mathrm{Ni}_{3} \mathrm{Al}$ and $\mathrm{Al}_{2} \mathrm{O}_{3}$," Journal of the American Ceramic Society, vol. 81, no. 7, pp. 1743-1748, 1998.

[12] T. Thamaraiselvi and S. Rajeswari, "Biological evaluation of bioceramic materials-a review," Trends in Biomaterials and Artificial Organs, vol. 18, no. 1, pp. 9-17, 2004.

[13] H. Zreiqat, C. R. Howlett, A. Zannettino et al., "Mechanisms of magnesium-stimulated adhesion of osteoblastic cells to commonly used orthopaedic implants," Journal of Biomedical Materials Research, vol. 62, no. 2, pp. 175-184, 2002.

[14] F. Witte, V. Kaese, H. Haferkamp et al., "In vivo corrosion of four magnesium alloys and the associated bone response," Biomaterials, vol. 26, no. 17, pp. 3557-3563, 2005.

[15] C. E. Wen, M. Mabuchi, Y. Yamada, K. Shimojima, Y. Chino, and T. Asahina, "Processing of biocompatible porous Ti and Mg," Scripta Materialia, vol. 45, no. 10, pp. 1147-1153, 2001.

[16] G. Song, "Recent progress in corrosion and protection of magnesium alloys," Advanced Engineering Materials, vol. 7, no. 7, pp. 563-586, 2005.

[17] S. S. A. El-Rahman, "Neuropathology of aluminum toxicity in rats (glutamate and GABA impairment)," Pharmacological Research, vol. 47, no. 3, pp. 189-194, 2003.

[18] Y. Nakamura, Y. Tsumura, Y. Tonogai, T. Shibata, and Y. Ito, "Differences in behavior among the chlorides of seven rare earth elements administered intravenously to rats," Toxicological Sciences, vol. 37, no. 2, pp. 106-116, 1997.

[19] J. Z. Ilich and J. E. Kerstetter, "Nutrition in bone health revisited: a story beyond calcium," Journal of the American College of Nutrition, vol. 19, no. 6, pp. 715-737, 2000.

[20] J. C. Oh, T. Ohkubo, T. Mukai, and K. Hono, “TEM and 3DAP characterization of an age-hardened $\mathrm{Mg}$-Ca-Zn alloy," Scripta Materialia, vol. 53, no. 6, pp. 675-679, 2005.

[21] G. Levi, S. Avraham, A. Zilberov, and M. Bamberger, "Solidification, solution treatment and age hardening of a Mg-1.6 wt.\% Ca-3.2 wt.\% Zn alloy," Acta Materialia, vol. 54, no. 2, pp. 523$530,2006$.

[22] T. Miyazaki, J. Kaneko, and M. Sugamata, "Structures and properties of rapidly solidified Mg-Ca based alloys," Materials Science and Engineering: A, vol. 181-182, pp. 1410-1414, 1994.

[23] C. Liu, Y. Xin, G. Tang, and P. K. Chu, "Influence of heat treatment on degradation behavior of bio-degradable die-cast AZ63 magnesium alloy in simulated body fluid," Materials Science and Engineering A, vol. 456, no. 1-2, pp. 350-357, 2007.

[24] X. Gu, Y. Zheng, Y. Cheng, S. Zhong, and T. Xi, "In vitro corrosion and biocompatibility of binary magnesium alloys," Biomaterials, vol. 30, no. 4, pp. 484-498, 2009.

[25] B. A. Shaw, Corrosion Resistance of Magnesium Alloys, vol. 13, ASM handbook, 2003.

[26] V. Kaesel, P. T. Tai, F. Bach, H. Haferkamp, F. Witte, and H. Windhagen, "Approach to control the corrosion of magnesium by alloying," in Magnesium: Proceedings of the 6th International Conference Magnesium Alloys and Their Applications, pp. 534539, Wiley Online Library, 2004.

[27] J. E. Gray and B. Luan, "Protective coatings on magnesium and its alloys-a critical review," Journal of Alloys and Compounds, vol. 336, no. 1-2, pp. 88-113, 2002.

[28] M.-C. Zhao, M. Liu, G. Song, and A. Atrens, "Influence of the $\beta$-phase morphology on the corrosion of the Mg alloy AZ91," Corrosion Science, vol. 50, no. 7, pp. 1939-1953, 2008.
[29] N. N. Aung and W. Zhou, "Effect of heat treatment on corrosion and electrochemical behaviour of AZ91D magnesium alloy," Journal of Applied Electrochemistry, vol. 32, no. 12, pp. 1397-1401, 2002.

[30] G. Song, A. L. Bowles, and D. H. StJohn, "Corrosion resistance of aged die cast magnesium alloy AZ91D," Materials Science and Engineering A, vol. 366, no. 1, pp. 74-86, 2004.

[31] M. Jönsson, D. Persson, and R. Gubner, "The initial steps of atmospheric corrosion on magnesium alloy AZ91D," Journal of the Electrochemical Society, vol. 154, no. 11, pp. C684-C691, 2007.

[32] T. Beldjoudi, C. Fiaud, and L. Robbiola, "Influence of homogenization and artificial aging heat treatments on corrosion behavior of Mg-Al alloys," Corrosion, vol. 49, no. 9, pp. 738-745, 1993.

[33] O. Lunder, J. E. Lein, T. K. Aune, and K. Nisancioglu, "Role of Mg17Al12 phase in the corrosion of Mg alloy AZ91," Corrosion, vol. 45, no. 9, pp. 741-748, 1989.

[34] D. L. Piron, The Electrochemistry of Corrosion, University of Houston, Houston, Tex, USA, 1991.

[35] G. Song, A. Atrens, D. Stjohn, J. Nairn, and Y. Li, “The electrochemical corrosion of pure magnesium in $1 \mathrm{~N} \mathrm{NaCl}$," Corrosion Science, vol. 39, no. 5, pp. 855-875, 1997.

[36] Z. Li, X. Gu, S. Lou, and Y. Zheng, "The development of binary $\mathrm{Mg}-\mathrm{Ca}$ alloys for use as biodegradable materials within bone," Biomaterials, vol. 29, no. 10, pp. 1329-1344, 2008.

[37] A. E. Coy, F. Viejo, P. Skeldon, and G. E. Thompson, "Susceptibility of rare-earth-magnesium alloys to micro-galvanic corrosion," Corrosion Science, vol. 52, no. 12, pp. 3896-3906, 2010.

[38] G. Song and A. Atrens, "Understanding magnesium corrosion-a framework for improved alloy performance," Advanced Engineering Materials, vol. 5, no. 12, pp. 837-858, 2003.

[39] A. F. Crawley and K. S. Milliken, "Precipitate morphology and orientation relationships in an aged Mg- $9 \% \mathrm{Al}-1 \% \mathrm{Zn}-0.3 \% \mathrm{Mn}$ alloy," Acta Metallurgica, vol. 22, no. 5, pp. 557-562, 1974.

[40] S. O. Sowemimo-Coker, "Red blood cell hemolysis during processing," Transfusion Medicine Reviews, vol. 16, no. 1, pp. 4660, 2002.

[41] ISO, "Biological evaluation of medical devices-Part 4: selection of tests for interactions with blood," Tech. Rep. ISO 10993$4,2002$. 

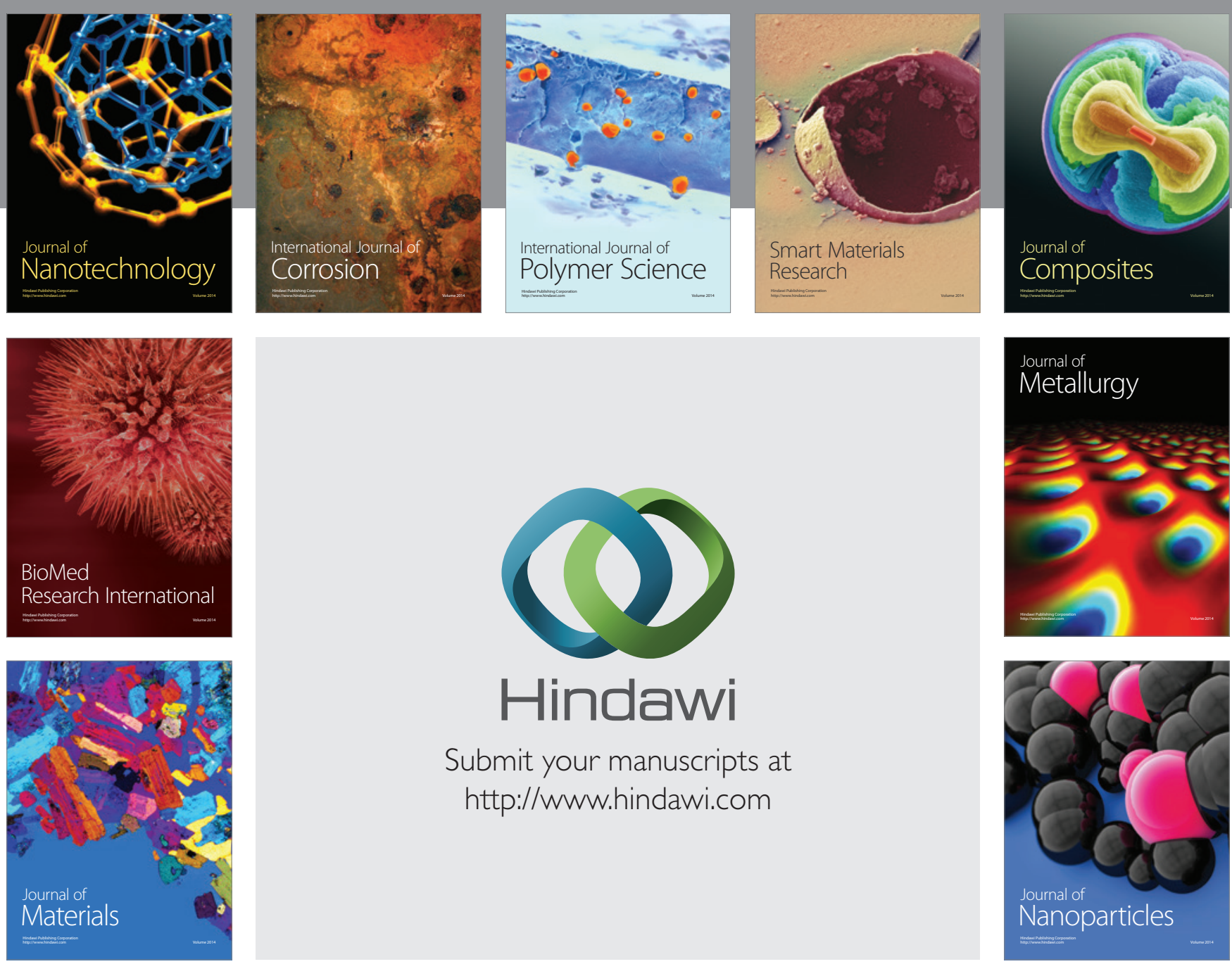

Submit your manuscripts at http://www.hindawi.com
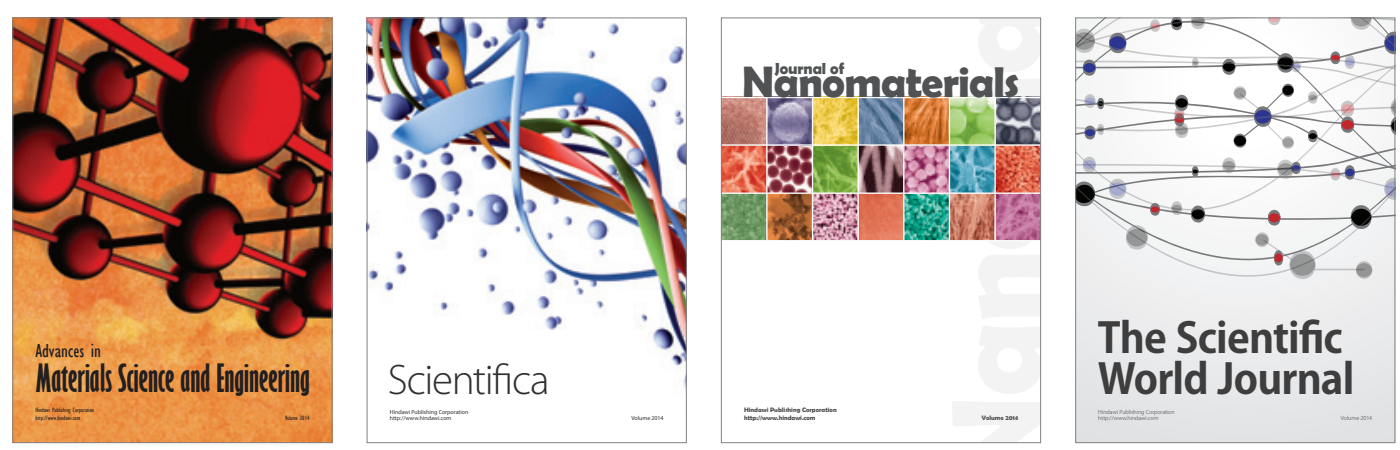

\section{The Scientific World Journal}
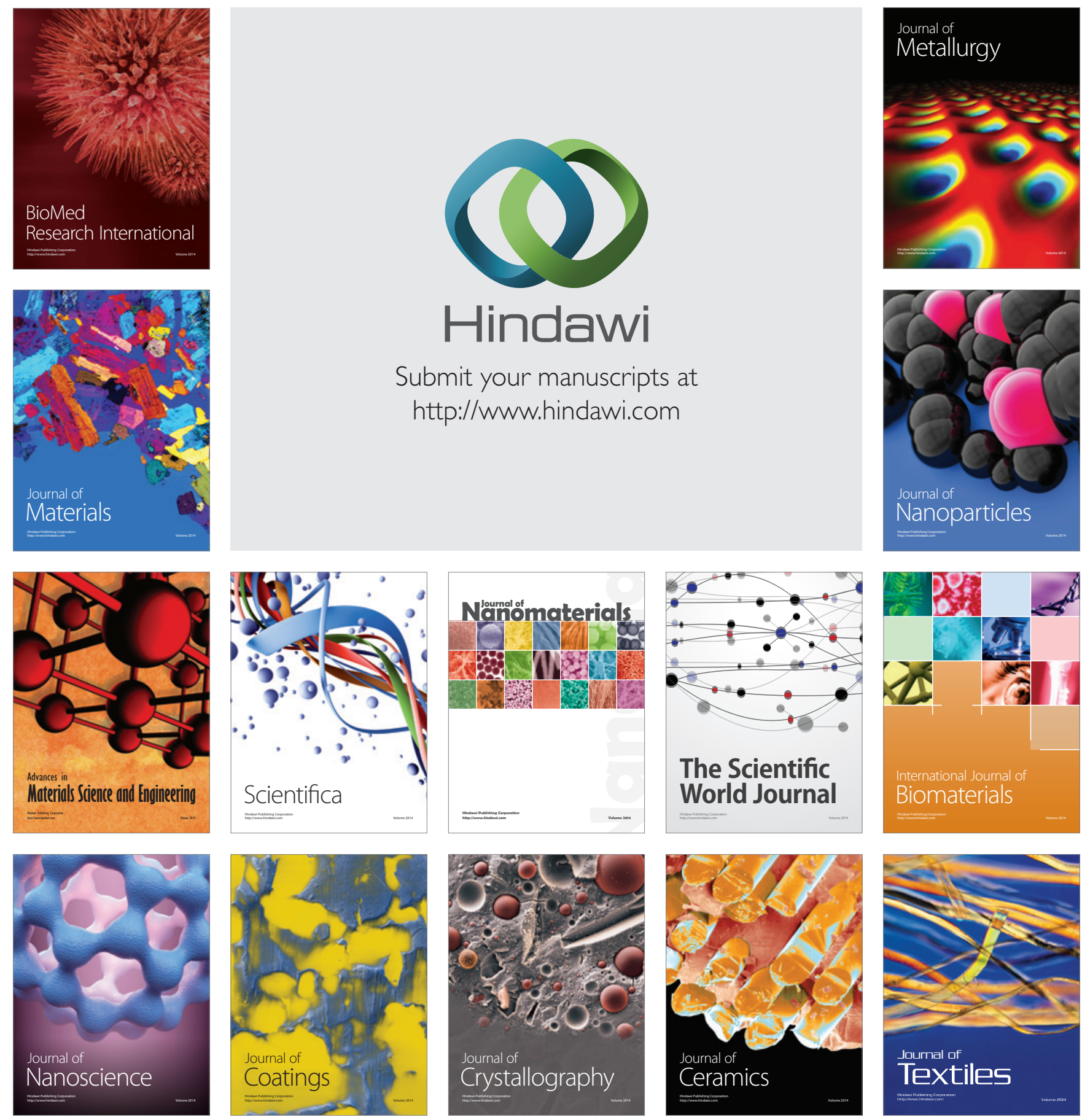